\title{
CRABP2 wt Allele
}

National Cancer Institute

\section{Source}

National Cancer Institute. CRABP2 wt Allele. NCI Thesaurus. Code C104926.

Human CRABP2 wild-type allele is located in the vicinity of $1 \mathrm{q} 21.3$ and is approximately 6 $\mathrm{kb}$ in length. This allele, which encodes cellular retinoic acid-binding protein 2 , is involved in both retinoic acid binding and retinoic acid signaling. 